\title{
Comparison of immunological specificity of gamma globulin in the cerebrospinal fluid in normal and multiple sclerosis subjects
}

\author{
E. A. CASPARY \\ From the Medical Research Council Research Group on Demyelinating Diseases, Royal Victoria Infirmary, \\ the University of Newcastle upon Tyne
}

It is generally agreed that $\gamma$ globulin concentration in spinal fluid is elevated in some $60 \%$ of cases of multiple sclerosis (Kabat, Freedman, Murray, and Knaub, 1950; Roboz, Hess, and Forster, 1953; Yahr, Goldensohn, and Kabat, 1954; Ivers, McKenzie, McGuckin, and Goldstein, 1961; Schapira and Park, 1961; Foster and Horn, 1962). Whilst little is known of its origin or direct pathological significance (Field and Ridley, 1960), in view of the possible immune pathogenesis of multiple sclerosis (Miller and Schapira, 1959) much interest has centred on this finding. Recently some workers have claimed to demonstrate minor globulin fractions not generally seen in normal cerebrospinal fluid (Dencker and Swahn, 1961 ; Kutt, McDowell, Chapman, Pert, and Hurwitz, 1960). However the bulk of $\gamma$ globulin in spinal fluid in cases of multiple sclerosis migrates with the same electrophoretic mobility as serum $\gamma$ globulin on all media.

The object of this work is to determine whether this pathologically increased $\gamma$ globulin is immunologically identical with that in 'normal' spinal fluid; and also to compare its immunological reactivity with serum globulin and with the products of brain degradation.

METHODS

PREPARATION OF $\gamma$ GLOBULIN Cerebrospinal fluid was concentrated to about $20 \%$ of its original volume by negative pressure filtration through Visking tubing. One or two $\mathrm{ml}$. of this concentrate was dialysed against $0.01 \mathrm{M}$ phosphate buffer, $p \mathrm{H} \mathrm{8}$, and applied to a DEAE cellulose column $(25 \times 1 \mathrm{~cm}$.) packed at $5 \mathrm{lb}$. per square inch and equilibrated with the same buffer. The column was then eluted with a $p H$ and molarity gradient system consisting of $0.01 \mathrm{M}$ phosphate $p \mathrm{H} 8$ and $0.3 \mathrm{M} \mathrm{NaH}_{2} \mathrm{PO}_{4}$ in a ratio of $1: 2$. Then $4 \mathrm{ml}$. fractions were collected and the protein concentration estimated by absorption at $280 \mathrm{~m} \mu$. The globulin fraction, the first to be eluted, was then dialysed against $0.75 \mathrm{M}$ saline and freeze dried. Human $\gamma$ globulin (G4) prepared by the method of
Kekwick and Mackay (1954) was kindly donated b Dr. R. A. Kekwick.

PREPARATION OF ANTISERA Normal adult rabbits $\mathbf{( 2 . 5}$ kg.) were given a course of four injections of $0.2 \mathrm{ml}$. of cerebrospinal fluid concentrate with Freund's complete adjuvant (Difco) intramuscularly into the thigh muscles of both hind legs at intervals of three to four days. Sera giving good precipitating reactions with cerebrospinal fluid proteins were obtained by bleeding the animals three weeks after this course of immunization. A few animals were given a further series of injections but no significant differences were observed in the antisera.

AGAR DIFFUSION This was done by the double diffusion method (Ouchterlony, 1949) using 0.8\% agar (Ionagar no. 2$)$ in normal saline containing $(0.0004 \%)$ azide as a bacteriostatic agent. The agar was cast either in Petri dishes selected for optical flatness or on microscope slides 3 in. $\times 2$ in. Wells of $5 \mathrm{~mm}$. diameter with an interwell distance of $10 \mathrm{~mm}$. were arranged in the requisite patterns and diffusion allowed to proceed at $4{ }^{\circ} \mathrm{C}$. Results were recorded by direct photography.

\section{RESULTS}

A typical example of the separation of protein fractions obtained from cerebrospinal fluid following elution on a DEAE column is shown in Figure 1. The $\gamma$ globulin is well separated from the other fractions

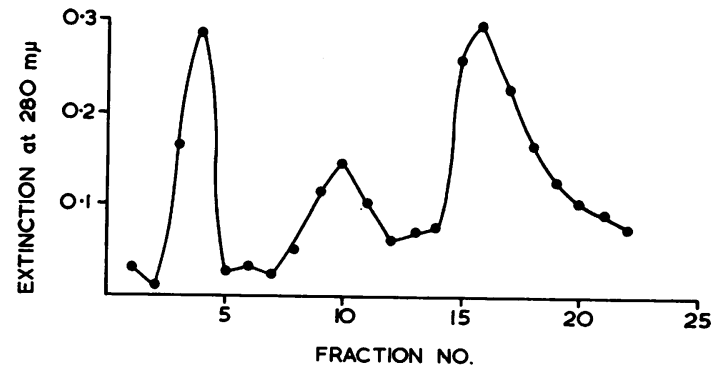

FIG. 1. Fractionation of multiple sclerosis spinal fluid on $D E A E$ cellulose; $\gamma$ globulin is the first sharp peak. 


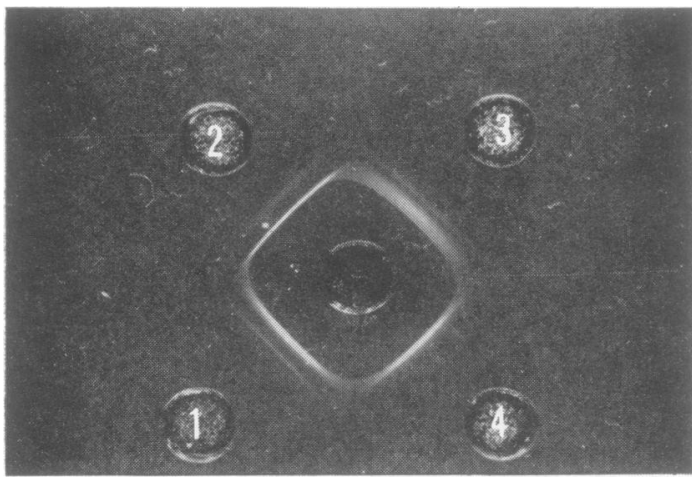

FIG. 2. Precipitation lines between anti-multiple sclerosis spinal fluid antiserum (centre well) and normal cerebrospinal fluid (1) and cerebrospinal fluid from cases of cerebral aneurysm (2), acute multiple sclerosis (3), and chronic multiple sclerosis (4).

and this was taken to denote freedom from contamination. Quantitation in these experiments was felt to be unjustifiable because of the concentration procedures and the deliberate bias introduced into the conditions of these experiments in order to obtain maximal separation of globulin for preparative purposes.

Figure 2 shows the reactions of antiserum to multiple sclerosis whole spinal fluid both with normal and multiple sclerosis spinal fluids. Complete reaction of identity for all visible lines is present, that is, for the major protein constituents. Similar results were obtained with antiserum to normal cerebrospinal fluid. More than 30 samples of multiple sclerosis spinal fluid have been examined by this method and the reactions of the major protein components, in particular the globulins, have always been those of identity. The faint line seen in cerebrospinal fluid from normal and acute cases of acute multiple sclerosis and normals is present in all cases, often too fine to reproduce photographically, and also gives the overall reaction of identity. Since gel diffusion experiments on spinal fluids concentrated by ultrafiltration or freeze drying and reconstitution showed no difference, most of this series of spinal fluids was freeze dried for convenience.

The reaction of anti-normal spinal fluid and antimultiple sclerosis spinal fluid antisera with $\gamma \vec{\circ}$ globulin fractions from normal and multiple sclerosis spinal fluid, and serum $\gamma$ globulin, also whole normal and multiple sclerosis spinal fluid, are shown in Figure 3. The globulin fractions give one continuous line of identity including the specific line in the whole cerebrospinal fluid with both these antisera. The human $\gamma$ globulin was prepared by different process and tends to give a more diffuse्f appearance in this test and also contains a trace of other contaminating serum proteins. In this ex@ $\vec{\imath}$ periment also no extra specific line or lines were $\mathbb{D}$ found to be associated with the isolated $\gamma$ globulig fractions from multiple sclerosis.

Absorption experiments with whole normal serune

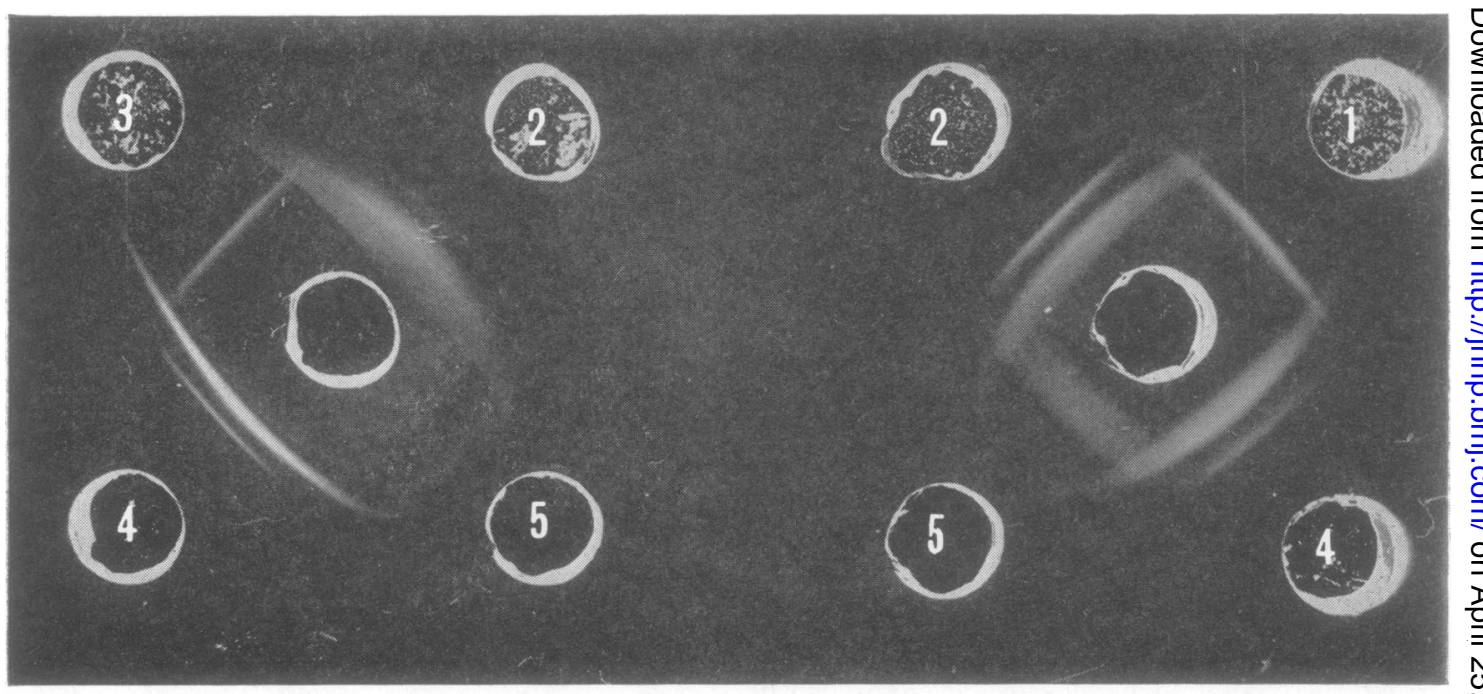

FIG. 3. Precipitation lines between anti-multiple sclerosis spinal fluid antiserum (left centre) and anti-normal spinal $N$ fluid antiserum (right centre) with normal cerebrospinal fluid $\gamma$ globulin (1), multiple sclerosis cerebrospinal fluid (2), $\mathrm{N}_{\mathrm{S}}$ multiple sclerosis cerebrospinal fluid $\gamma$ globulin (3), normal cerebrospinal fluid (4), serum $\gamma$ globulin (5). 
or serum globulin designed to attempt to remove all antibodies to normal serum or cerebrospinal fluid led to total elimination of reaction with globulin in serum and cerebrospinal fluid (both normal and multiple sclerotic). This accords with the immune identity of the serum and cerebrospinal fluid globulin in normal and multiple sclerotics noted above.

Attempts to demonstrate antigens specific to brain in spinal fluids using anti-brain serum were not successful, and the converse experiments using anti-spinal fluid serum and brain antigens were equally negative. However, it is difficult to show brain specific antigens by gel diffusion (Caspary and Field, 1963) and at very low concentration in spinal fluid these antigens may not be demonstrable by this method.

\section{DISCUSSION}

The present study shows that antiserum against the proteins of normal and multiple sclerotic cerebrospinal fluid reacts equally well with isolated fractions of $\gamma$ globulin from either source and those from normal human serum. These findings are substantially in accord with those of Rosenthal and Soothill (1962) who used antisera prepared against the proteins of serum alone.

In the context of these experiments the minor deviations of protein distribution that have been described in the cerebrospinal fluid following a number of clinical conditions have been ignored, on the basis that the marked rise of globulin concentration in multiple sclerosis cannot be attributed to a spectacular rise in any one or in a number of these abnormal components. These deviations could arise from at least two causes: first, a highly selective filtration through the blood cerebrospinal fluid barrier tending to favour, for example, molecules of a certain size, shape, and/or charge, and therefore allowing a concentration of fractions not normally detectable; or secondly, these minor protein deviations may be products of protein degradation arising from brain destruction and classified as $\gamma$ globulins purely on the basis of their electrophoretic mobility. The globulin described as 'peculiar to the cerebrospinal fluid' by MacPherson and Cosgrove (1961) may well fall into the latter category. It is found in all spinal fluids, regardless of the underlying clinical conditions and can only be demonstrated with antisera prepared against spinal fluid. This 'globulin' may well be related to, or be identical with, the soluble product (Caspary and Field, 1963) from human brain and be a normal finding, since MacPherson and Cosgrove (1961) showed no increase in this fraction when brain tissue disintegration was present in the patient. Practical considerations do not permit the application of the methods of Porter (1963) and others for investigating the structure of globulins and splitting the molecule into A and B chains for detailed comparison with the serum globulins. The common structural determinant of globulin is the B chain and functional antigenic differences between them appear to be located on the A chain; only studies of this kind will finally give the answer to the problem whether these aberrant 'globulins' are, in fact, globulin or cerebral breakdown products not containing the common structural determinant.

The bulk of the increased globulin in cases of multiple sclerosis has been shown to react both with antisera prepared against serum and cerebrospinal fluid proteins and must by definition contain the normal A chains to which antibody response normally occurs. The origin of this increase is more difficult to define. By far the most simple explanation would be a selectively increased permeability of the blood-cerebrospinal fluid barrier operating in favour of $\gamma$ globulin as compared with the albumin present in normal concentration, and since these proteins are widely separated in electric charge such a mechanism is readily conceivable. Frick and Scheid-Seydel (1958), studying this problem using radio-iodinelabelled globulin, suggest that the increase arises within the subarachnoid space on the basis of the distribution of labelled and unlabelled globulin molecules in the serum and cerebrospinal fluid of patients with multiple sclerosis. On the other hand, studies of the concentrations of antibodies following immunization show a remarkably constant ratio of cerebrospinal fluid to blood titres, and, as this ratio is altered in multiple sclerosis (Clark, 1963), this points towards an altered permeability. If the globulin is formed within the brain then the questions arise, Where, to what stimulus, and with what function? Many investigators have searched for antibodies in the cerebrospinal fluid to brain or brain derivatives with no apparent success. A reduction in complement (C') apparently correlating with high $\gamma$ globulin has been shown in multiple sclerosis by Kuwert, Firnhaber, and Pette (1964) but this negative finding is unlikely to explain the increase in $\gamma$ globulin. Ridley (1962) showed that the mononuclear perivascular cuffs in experimental allergic encephalomyelitis of guinea-pigs contained quantities of $\gamma$ globulin. Whilst this has not yet been shown in multiple sclerosis it is difficult to conceive the relatively small number of cells present in this condition producing globulin in such high yield. However, Field (1954) found an association between raised $\gamma$ globulin level and elevated lymphocyte count in multiple sclerosis and in patients receiving intrathecal tuberculin. He suggested that 'accumulations of 
lymphoid tissue in the central nervous system may be the source of the locally produced $\gamma$ globulin'. The production of normal non-antibody $\gamma$ globulin in response to antigenic stimulus has been demonstrated by Askonas and Humphrey (1958) and our inability to demonstrate specific antibody activity in cerebrospinal fluid may be a result of antibody binding in the tissue leaving only the non-specific $\gamma$ globulin unbound. This might also account for the failure of Field and Ridley (1960) to demonstrate antibody by the $\gamma$ globulin consumption test (Steffen, 1954), since their experimental method could not detect antibody unless it exceeded $7 \%$ of total $\gamma$ globulin.

\section{SUMMARY}

Antibodies prepared against the proteins of normal serum and those of normal and multiple sclerotic spinal fluids indicate the immune identity of $\gamma$ globulin from all three sources. The possible significance and origin of the increased globulin in multiple sclerosis is discussed.

I would like to thank Dr. E. J. Field for suggesting this study and for advice and encouragement and Professor Henry Miller and Dr. G. L. Gryspeerdt for numerous samples of spinal fluid.

\section{REFERENCES}

Askonas, B. A., and Humphrey, J. H. (1958). Formation of specific antibodies and $\gamma$-globulin in vitro. A study of the synthetic ability of various tissues from rabbits immunized by different methods. Biochem. J., 68, 252-261.

Caspary, E. A., and Field, E. J. (1963). Immunological examination of the soluble antigens of human brain and their modification by proteolytic enzymes. Dtsch. $Z$. Nervenheilk., 184, 478-486.

Clark, D. (1963). Unpublished observations.

Dencker, S. J., and Swahn, B. (1961). Clinical value of protein analysis in cerebrospinal fluid. Lunds Universitets Arsskrift. N.F. Avd 2, 57, No. 10.

Field, E. J., and Ridley, A. (1960). Cerebrospinal fluid $\gamma$-globulin in multiple sclerosis. Brit. med. J., 11, 1053.
Field, E. O. (1954). The production of gamma globulin in the central nervous system. J. Neurol. Neurosurg. Psychiat., 17, 228-232.

Foster, J. B., and Horn, D. B. (1962). Multiple sclerosis and spinalfluid- $\gamma$-globulin. Brit. med. J., 1, 1527.

Frick, E., and Scheid-Seydel, L. (1958). Untersuchungen mit J'131markiertem $\gamma$-Globulin zur Frage der Abstammung der Liquoreiweisskörper. Klin. Wschr., 36, 857-863.

Ivers, R. R., McKenzie, B. F., McGuckin, W. F., and Goldstein, N. P. (1961). Spinal fluid $\gamma$-globulin in multiple sclerosis and other neurological diseases. Electrophoretic patterns in 606 patients. J. Amer. med. Ass., 176, 515-519.

Kabat, E. A., Freedman, D. A., Murray, J. P., and Knaub, V. (1950). A study of the crystalline albumin, $\gamma$-globulin and total protein in the cerebrospinal fluid of one hundred cases of multiple sclerosis and in other diseases. Amer. J. med. Sci., 219, 55-64.

Kekwick, R. A., and Mackay, M. E. (1954). The separation of protein fractions from human plasma with ether. Spec. Rep. Ser. med. Res. Coun. (Lond.), No. 286.

Kutt, H McDowell, F., Chapman, L., Pert, J. H., and Hurwitz, L. J. (1960). Abnormal protein fractions of cerebrospinal fluid demonstrated by starch gel electrophoresis. Neurology (Minneap.), 10, 1064-1067.

Kuwert, E., Firnhaber, W., and Pette, E. (1964). Demonstration of complement in spinal fluid in demyelinating diseases. Proc. N.Y. Acad. Sci., in press.

MacPherson, C. F. C., and Cosgrove, J. B. R. (1961). Immunochemical evidence for a gamma globulin peculiar to cerebrospinal fluid. Canad. J. Biochem., 39, 1567-1574.

Miller, H. G., and Schapira, K. (1959). Aetiological aspects of multiple sclerosis. Brit. med. J., 1, 737-740, 811-814.

Ouchterlony, O. (1949). Antigen-antibody reactions in gels. Acta path. microbiol. scand., 26, 507-515.

Porter, R. R. (1963). Chemical structure of $\gamma$-globulin and antibodies.T Brit. med. Bull., 19, 197-201.

Ridley, A. (1962). A study of immunity changes in experimentad allergic encephalomyelitis by means of the fluorescent antibodp method. Ph.D. thesis, University of Durham.

Roboz, E., Hess, W. C., and Forster, F. M. (1953). Quantitative determination of gamma globulin in cerebrospinal fluid. ItS $\mathbb{D}$ application in multiple sclerosis. Neurology (Minneap.), 3 410-416.

Rosenthal, F. D., and Soothill, J. F. (1962). An immunochemica9 study of the proteins in cerebrospinal fluid. J. Neurol. Neuro surg. Psychiat., 25, 177-181.

Schapira, K., and Park, D. C. (1961). Gamma globulin studies io multiple sclerosis and their application to the problem of diagnosis. Ibid., 24, 121-124.

Steffen, C. (1954). Untersuchung über das Vorkommen eines in Polyarthritikerseren und in Seren von Endokarditiskranken aufscheinenden und an Bindegewebszellen sessil werdenden Antikörpers. Wien Z. inn. Med., 35, 422-429.

Yahr, M. D., Goldensohn, S. S., and Kabat. E. A. (1954). Further studies on the $\gamma$-globulin content of cerebrospinal fluid in multiple sclerosis and other neurological diseases. Ann. N.Y. Acad. Sci., 58, 613-624. 